\title{
Controlling m-Stacking Interactions in a Series of Novel Heteroacene Derivatives
}

\author{
L. Hiscock, L. Dawe, K. Maly \\ Wilfrid Laurier University, Waterloo, Canada
}

hisc2250@mylaurier.ca

The understanding and control of intermolecular forces allows for the creation of supramolecular architectures held together by relatively weak, flexible interactions. The exploitation of $\pi-\pi$ stacking interactions can produce materials with dynamic properties such as crystal to crystal transitions.[1] Co-facial $\pi$-interactions are also important in the preparation of semiconducting organic materials,[2] however, face-to-face $\pi$-stacking is generally repulsive and often disfavoured.[3]

In our development of an $\mathrm{S}_{\mathrm{N}} \mathrm{Ar}$-based methodology for the synthesis of heteropentacene analogues 1a-c we synthesised a series of electronically biased 1,2,3,4-tetrasubstituted dibenzodioxin (2a-c) and phenoxazine (3a-c) derivatives.[4] An examination of the crystal structures of $\mathbf{2 a - c}$ and 3a-c indicates that a combination of electronic bias and $\mathrm{C}-\mathrm{H}$ substitution affords compounds which tend to $\pi$-stack in a co-facial, antiparallel manner. A search of the Cambridge Structural database for representative structures was also conducted. The results indicate such motifs could be valuable building blocks for supramolecular design of materials held together by co-facial $\pi-\pi$ stacking interactions.<smiles>Oc1ccccc1O</smiles><smiles>[R]c1c(F)c(F)c([R])c(F)c1F</smiles><smiles>CCC</smiles><smiles>[R]c1c2oc3ccccc3oc2c([R])c2oc3ccccc3oc12</smiles>

$$
\begin{aligned}
& \text { 1a, } R=C N \\
& 1 \text { b, } R=F \\
& 1 c, R=B r
\end{aligned}
$$<smiles>[R]c1c(F)c(F)c([R])c2c1Oc1ccccc1O2</smiles>

2a, $R=C N$

2b, $R=F$

2c, $\mathrm{R}=\mathrm{Br}$<smiles>[R]N1c2ccccc2Oc2c(C#N)c(F)c(F)c(C#N)c21</smiles>

3a, $\mathrm{R}=\mathrm{H}$

3b, $\mathrm{R}=\mathrm{Et}$

3c, $R=B n$

[1] Reger, D. L.; Horger, J. J.; Smith, M. D.; Long, G. J.; Grandjean, F. Inorg. Chem. 2011, 50 (2), 686-704.

[2] Anthony, J. E. Angew. Chem. Int. Ed. 2008, 47 (3), 452-483.

[3] Hunter, C. A.; Sanders, J. K. M. J. Am. Chem. Soc. 1990, 112 (14), 5525-5534.

[4] Hiscock, L. K.; Raycraft, B. M.; Wałęsa-Chorab, M.; Cambe, C.; Malinge, A.; Skene, W. G.; Taing, H.; Eichhorn, S. H.; Dawe, L. N.; Maly, K. E. Chem. Eur. J. 2019, 25 (4), 1018-1028.

Keywords: Pi-pi stacking, non-covalent interactions, crystal engineering 